\title{
KURIKULUM HUMANISTIK DAN PENDIDIKAN KARAKTER: SEBUAH GAGASAN PENGEMBANGAN KURIKULUM MASA DEPAN
}

\author{
Dwi Setiyadi *
}

\begin{abstract}
Humanistic curriculum gives rise to the coverage of need of selfactualization of the students so as to develop and to build integrity. The social reconstructionists suggests that social needs are available in any individual interest. The obligation of a curriculum is to generate the better future through a social reformation. Social values and their application should be accommodated in critical thinking process framed by a curriculum; in the way that curriculum has become the best vehicle for the students to develop their skill in grasping with the learning materials, understanding the personal and local problems. Personality, social values, thinking skill, problem solving skill can be all developed altogether through a curriculum - which in return can bring about the better future of human nature.
\end{abstract}

Key words: Humanistic Curriculum, Character Education, Future Curriculum Development

\begin{abstract}
Abstrak
Konsepsi-konsepsi yang paling menonjol mengenai kurikulum bisa diklasifikasikan menjadi empat golongan, yaitu: humanistik, rekonstruksionalis sosial, teknologis, dan akademik. Perumus dari tiap-tiap jenis kurikulum tersebut masing-masing memiliki pertanyaan yang berbeda mengenai kurikulum: apa yang harus diajarkan? Kepada siapa? Kapan? Dan bagaimana? Para penganut kurikulum humanis menyarankan bahwa sebuah kurikulum seharusnya memberikan wadah bagi pengalaman pribadi yang memuaskan bagi setiap siswa. Para humanis baru merupakan pelaku aktualisasi diri yang melihat kurikulum sebagai sebuah proses liberasi yang memenuhi kebutuhan akan pertumbuhan dan integritas pribadi. Namun demikian para humanis tersebut jangan diartikan sebagai pendidik dalam tradisi seni liberal yang menganggap humaniora sebagai disiplin ilmu yang terpisah, seperti: seni, musik, dan sastra, dan mereka yang berusaha untuk berhubungan dengan manusia hanya melalui karya kultural. Para rekonstruksionis sosial menekankan kebutuhan sosial yang terdapat pada kepentingan
\end{abstract}

* Dwi Setiyadi adalah Dosen Prodi Pendidikan Bahasa Inggris IKIP PGRI Madiun 
individual. Mereka menyatakan bahwa tanggung jawab sebuah kurikulum adalah untuk melakukan reformasi sosial dan menurunkan masa depan yang lebih baik bagi masyarakat. Mereka menekankan perkembangan nilai-nilai sosial dan penerapannya di dalam proses berpikir kritis. Teknologis melihat penyusunan kurikulum merupakan sebuah proses teknologis untuk meraih apa yang dikehendaki oleh pembuat kebijakan. Mereka menganggap dirinya bertanggung jawab untuk menciptakan realita yang menunjukkan bahwa kurikulum yang mereka susun sesuai dengan tujuan yang dikehendaki. Efisiensi dan akuntabilitas merupakan nilai akhir bagi seorang teknolog. Orientasi mereka tidaklah netral karena teknolog memiliki komitmen terhadap suatu metode yang akhirnya akan berpengaruh terhadap tujuan dan isi kurikulum. Orang yang memiliki orientasi akademik memandang kurikulum sebagai kendaraan yang bisa digunakan oleh pembelajar untuk mengenali disiplin ilmu dan mengenali bidang-bidang ilmu yang terorganisir. Mereka melihat isi yang terorganisir dari disiplin ilmu tersebut lebih sebagai sebuah kurikulum yang harus dicapai daripada sebuah sumber informasi untuk mendalami masalah personal dan lokal. Orang yang termasuk dalam kategori ini menganggap bahwa kurikulum akademik merupakan cara terbaik untuk mengembangkan pemikiran - bahwa penguasaan sejenis pengetahuan yang biasa ditemukan pada kurikulum semacam itu akan membentuk cara berpikir rasional.

Kata Kunci: Pembelajaran IPS, Pendidikan Karakter

\section{A. Pendahuluan}

Kurikulum humanistik seringkali menimbulkan konotasi negatif - yang dianggap sebagai anti-ilmiah, kata-kata indah, pelipur lara yang tidak secara langsung berhubungan dengan kehidupan nyata. Pada tahun 1980-an orientasi kurikulum mengalami perubahan yang berorientasi pada kepentingan, pertumbuhan alami, dan irama aksi siswa. Alasannya adalah bahwa kurikulum terdahulu melupakan kebutuhan dasar orang untuk menjalani hidup. Kebutuhan pendidikan semua orang dianggap sama yaitu bagaimana untuk membekali ketrampilan untuk mendapatkan pekerjaan.

Pada tahun 1990-an, kurikulum lebih bersifat Outcome Based Education (OEB) yang menekankan pada hasil lulusan yang memiliki nilai diri, menghargai sesama tanpa diskriminasi, memiliki ketangguhan fisik, emosi dan sosial. Hal-hal tersebut akan bisa didapatkan denagn kurikulum humanistik. Pada tahun 1994 C. Everette Koop Institute mendidik siswa kedokteran yang memiliki kepekaan terhadap sisi kemanusiaan dari hubungan dokter-pasien dengan cara mengurangi kuliah di kelas dan laboratorium namun memperbanyak bergaul dengan keluarga, memahami emosi dan sebagainya. Inti dari kurikulum humnistik adalah membentuk perkembangan kepribadian, pembelajaran, dan aktualisasi-diri. 


\section{B. Pembahasan}

\section{Ciri-ciri Kurikulum Humanistik}

Tujuan pendidikan menurut kurikulum humanistik adalah membentuk proses kepribadian yang berkaitan dengan kondisi ideal pertumbuhan kepribadian, integritas, dan otonomi. Diri haruslah dibuka, dibentuk dan diajari. Kurikulum humanistik banyak dipengaruhi oleh Psikologi angkatan ketiga yang banyak mendorong adanya aktualisasi diri, di mana pembelajar dibiarkan berekspresi, bertindak, bereksperimen, bahkan membuat kesalahan, dilihat dan mendapatkan umpan balik, serta menemukan siapa diri mereka. Kita akan belajar mengenali diri kita sendiri melalui respon terhadap pengalaman puncak. Melalui meditasi dan disiplin spiritual, seseorang bisa mengendalikan kesadarannya.

Pada akhirnya melalui kurikulum humanistik ini, pembelajar akan belajar untuk mengenali tantangan, mengubah nasib menjadi tugas-tugas yang bisa diatur, dan mempercayai kemampuannya. Siswa diharapkan memahami hubungan sebab akibat di mana emosi dan imajinasi dilatih untuk merespon akibat-akibat dari sebuah aksi, pembelajar akan tumbuh dalam kesadaran atas kompleksitas dan mampu bertahan di masa datang. Fungsi guru yang terpenting bagi siswa adalah: (1) mendengarkan secara keseluruhan pandangan siswa mengenai realita; (2) menghargai siswa; dan (3) berbuatlah yang wajar dan apa adanya, tidak dibuatbuat.

\section{Dasar Pemilihan Kesempatan Belajar}

Kesadaran diri diyakini bisa didapatkan melalui memahami perasaan dirinya sendiri. Mengkaji pikiran sendiri seseorang - kalimat, dialog, fantasi merupakan alat untuk mendapatkan kesadaran diri. Juga mempelajari aksi dan gerakan personal serta ekspresi fisik. Kurikulum humanistik meningkatkan kesadaran diri, yang memungkinkan pembelajar mencari pola personal khusus dalam respon mereka sendiri terhadap serangkaian aktivitas. Penerimaan, bukannya penolakan atas pola diri seseorang sangat penting untuk mengubah aspek diri. Kurikulum huanistik ditandai dengan aktivitas-aktivitas yang menyerupai permainan yang betujuan untuk mendorong pertumbuhan personal dan terlebih lagi untuk mengkaji kehidupan dalam dari pembelajar dalam proses belajar, dalam hal mendapatkan pengetahuan mata pelajaran, pelatihan atau ketrampilan dasar.

Dimensi-dimensi pengalaman afektif meliputi: (1) menyusun aktivitas untuk mengungkapkan pemikiran pribadi dan hambatannya seperti ketakutan, keinginan yang tidak terpenuhi mengenai keamanan dan kemakmuran; (2) memperkenalkan materi dan aktivitas dalam bentuk topik-topik, mata pelajaran dan tugas pembelajaran yang menarik bagi siswa dan yang berhubungan dengan tema-tema yang menyatu dengan pengungkapan pemikiran siswa; (3) menawarkan aktivitas yang menyenangkan dan berharga bagi mereka; dan (4) melibatkan mereka dalam aktivitas yang berfokus pada prestasi yang pernah didapatkan, termasuk penguasaan dan kepuasan suatu hal.

Berbeda dengan kurikulum lain, humanistik kurikulum menekankan pertumbuhan, tidak peduli seberapapun ukurannya. Evaluasi akan lebih 
menekankan pada proses bukan hasil. Penguji akan menanyakan apakah aktivitassktivitas yang dilakukannya mampu memberikan bantuan bagi siswa untuk lebih berkembang, terbuka dan mandiri. Aktivitas dilpandang penting dalam membentuk nilai di masa datang. Kelas yang baik akan memberikan kesempatan bagi siswa untuk menjadi sadar diri dan orang lain serta mengembangkan potensi yang ada pada dirinya.

\section{Arah Kurikulum Humanistik}

Kurikulum humanistik difokuskan pada pertumbuhan manusia yang sekaligus responsif terhadap tekanan publik untuk berprestasi. Bagian terpenting dari kesatuan pendidikan adalah integrasi antara domain afektif (emosi, sikap, nilai) dan domain kognitif (pengetahuan intelektual dan kemampuan pikir). Tujuan kurikulum adalah untuk memberikan alternatif pilihan pada siswa atas hidup, bertanggung jawab atas pilihannya, dan menyadari bahwa mereka bisa memilih. Unsur-unsur kurikulum tersebut adalah: (1) partisipasi; (2) integrasi; (3) relevansi; (4) diri; dan (5) tujuan. Kurikulum tidak hanya melibatkan aspek kesadaran kognitif namun juga aspek kesadaran intuitif - dengan bimbingan melalui fantasi dan meditasi. Praktik ini telah diterapkam pada kurikulum SMU untuk menghindari penyalahgunaan obat bius. Aktivitas ini kemudian dikembangkan ke dalam intelegensi kreatif yang membangkitkan kemampuan berpikir.

Belajar mandiri merupakan respons terhadap ancaman depersonalisasi yang disebabkan oleh fokussempit atas ketrampilan dasar dari membaca, menulis dan aritmatika. Perencanaan kurikulum untuk menghasilkan siswa belajar mandiri adalah: motivasi berprestasi, teori atributif, kepentingan anak, lokus kontrol. Kurikulum humanistik bertujuan mengembangkan bidang-bidang: kognitif, afektif, sosial, moral, dan perkembangan ego. Kritik terhadap kurikulum humanistik terdiri dari tiga hal, yakni: (1) lebih menekankan pada metode, teknik dan pengalaman, dan tidak menekankan pada akibat atau hasil bagi siswa; (2) tidak begitu memperhatikan pengalaman pribadi, namun lebih menekankan pada keseragaman; dan (3) kurang memberikan penekanan pada perorangan, yang lebih menekankan kebutuhan sosial.

\section{Kurikulum Subjek Akademik}

Pada tahun 1970-an kurikulum diarahkan pada kepentingan-kepentingan sosial (pendidikan multikultural, pendidikan karir, pemahaman fungsional) dan kepentingan di luar akademik. Pada tahun 1980-an kurikulum ditekankan pada relevansi personal dan sosial. Salah satu alasan yang terkuat adalah adanya anggapan bahwa sistem pendidikan Jepang dianggap lebih baik. Ada empat kriteria bentuk pengetahuan kognitif untuk memahami dunia: (1) konsep yang memiliki bentuk tertentu; (2) setiap bentuk memiliki struktur logis yang berbeda; (3) bentuk tersebut memiliki pernyataan atau kesimpulan yang bisa diuji; dan (4) bentuk tersebut memiliki metode untuk mendapatkan pengalaman belajar dan menguji pernyataan-pernyataan. Menurut Hirst kurikulum dinamis lebih menekankan pada bentuk pengetahuan daripada substansi dari subjek. Baginya pengetahuan meliputi cara untuk menyusun pengalaman sehinga bisa 
dipublikasikan, dibagikan, dan bersifat instrumental atau berguna untuk kehidupan sehari-hari.

Struktur dalam disiplin-disiplin ilmu merupakan dasar dari isi kurikulum, yang mengacu pada tatanan untuk melakukan inquiry dan mendapatkan kebenaran dalam disiplin ilmu tertentu. Ada tiga macam struktur yaitu: (1) struktur organisasional; (2) struktur substantif; dan (3) struktur sintaktik. Metode tertentu yang digunakan untuk melakukan tugas itu akan membentuk syntax dari sebuah disiplin ilmu. Gowin mengajukan lima pertanyaan untuk menyusun sebuah struktur pengetahuan dalam sebuah kurikulum: (1) apa pertanyaan berceritanya? (2) apa konsep kuncinya? (3) apa metode yang digunakan untuk menjawab pertanyaan bercerita itu? (4) Apa klaim utama atas karya tersebut? dan (5) nilai apa yang dihasilkan? Konsep dari disiplin-disiplin ilmu digunakan untuk merancang kurikulum di mana siswa diharapkan bisa belajar bagaimana para ahli menemukan pengetahuan. Program ini bisa dimulai sejak taman kanak-kanak. Ada beberapa pro dan kontra terhadap program baru yang dianggap hanya memberikan siswa untuk menjadi ilmuwan profesional dan ahli matematika.

Guru yang tidak pernah melakukan temuan ilmiah sendiri, akan mengalami kesulitan dalam membimbing siswa untuk melakukan temuan, sehingga validitas sebuah kurikulum akan dipertanyakan dengan alasan bahwa konsep didapatkan setelah mengkaji fakta. Proyek reformasi tersebut tidak memberikandampak positif bagi siswa berprestasi rendah, sedangkan perubahan perilaku sosial siswa lebih nampak berpengaruh. Ketidakpercayaan terhadap kurikulum pengetahuan timbul karena ketidakmampuan ilmuwan untuk menyelesaikan masalah humaniora.

\section{Keberterimaan Disciplin Approach}

Struktur di dalam disciplin approah akhirnya diterima kembali, ketika semua laporan pendidikan nasional menghendaki kurikulum yang berpusat pada ketrampilan 'tingkat tinggi' dalam bidang membaca, menulis, matematika, penyelesaian masalah dan penalaran abstrak. Kurikulum diharapkan mampu menjadikan siswa belajar daripada menerima kesimpulan jadi. Pro dan kontra atas pengetahuan terjadi ketika para perancang bentuk pengetahuan dan struktur disiplin ilmu menolak pandangan yang kaku terhadap pengetahuan dan menyatakan bahwa pengetahuan sifatnya tentative. Penciptaan pengetahuan pernyataan, kesimpulan dan kebenaran yang valid - terjadi mengikuti sistem inquiry dari disiplin ilmu khusus atau bentuk kognitif. Mereka menolak praktik siswa yang menerima kesimpulan tanpa metode dan teori yang mendukungnya.

Seni liberal telah berkembang pada bidang bahasa, seni kreatif, seni ekspresif, dan beberapa subjek lain dipercayai memiliki kekuatan untuk mengendalikan imaginasi, mengembangkan apresiasi terhadap kecantikan, serta membuka hakikat kemanusiaan. Seni liberal dalam pendidikan tinggi banyak mendapatkan serangan karena dianggap gagal melakukan diseminasi tradisi luhur dari filosofi, sastra dan seni. Sejak tahun 1980-an timbul banyak konflik antara mereka yang menghendaki koherensi di dalam kurikulum dan mereka yang menghendaki untuk memberikan kesempatan bagi siswa belajar spesialisasi atas pilihannya sendiri. 
Pada tahun 1982 Havard University mengembangkan kurikulum yang mengedepankan tujuan umum dan koherensi dalam proses pembelajaran yang mampu mengubah sampai $80 \%$ pembelajaran spesialisasi. Isi kurikulum inti akan memiliki hal-hal: (1) apa hubungan antara karya yang secara tradisional dianggap luhur dengan karya tulisan yang mencerminkan pengalaman orang lain; dan (2) haruskah 'buku-buku induk' digunakan sebagai acuan terhadap nilai umum dan muatan tradisi, atau research dan konteks kontemporer bisa dikaji ulang dengan cara baru untuk memahami nilai kelasik. Banyak sekolah yang menawarkan kurikulum berdasar pada proporsi yang mengandung kebenaran absolut, valid dalam semua kondisi, atau bahwa alasan bisa dicapai dengan cara yang yang mudah dengan menggunakan karya intektual besar kemanusiaan.

Seni liberal dalam kurikulum sekolah dasar dan menengah pada tahun 1982 memberikan satu program tunggal dan inti akademik umum di mana siswa akan belajar bahasa asli, sastra, seni rupa, matematika, ilmu pengetahuan alam, sejarah geografi dan ilmu-ilmu sosial. Hal penting dalam kurikulum ini adalah: (1) pendidikan umum dan ketimpangan umum tidak bisa dipisahkan; dan (2) pendidikan bagi semua tingkatan (kelas 1 s.d. 12) harus bersifat liberal, tidak bersifat spesifik atau okupasional. Para perumus kurikulum baru menginginkan kurikulum bisa memberikan lebih dari sekedar fakta dengan menghubungkan pengetahuan faktual dengan dunia kultural untuk membentuk kepakaan rasa siswa. Ada tiga tujuan utama kurikulum yaitu: (1) pengetahuan yang berasal dari pemahaman kultural; (2) pemahaman demokrasi dan kewarganegaraan; dan (3) kemampuan partisipasi sebagai warganegara.

\section{Karakteristik Kurikulum sebagai Subjek Akademik}

Kurikulum sebagai subjek akademik memiliki bangun yang meliputi: (1) tujuan; (2) metode; (3) organisasi; dan (4) evaluasi. Tujuan dari kurikulum akadenik adalah mengembangkan pemikiran rasional, melatih siswa melakukan research, dan membentuk keajegan, makna atau tradisi sosial. Metode, eksposisi dan inquiry merupakan teknik yang paling umum digunakan dalam kurikulum akdemik. Gagasan disampaikan secara jelas agar mudah diterima. Metode yang tepat untuk menguji sebuah kebenaran harus diajarkan. Siswa harus mampu memahami bahwa alasan dan persepsi selalu digunakan dalam mendapatkan pengetahuan di bidang ilmu, logika matematik, bentuk dan perasaan individual, serta koherensi dalam sejarah. Siswa diharapkan membaca karya-karya besar untuk mengembangkan pengetahuannya. Organisasi, program interdisipliner merupakan bentuk organsasi kurikulum akademik, misalnya matematika berkaitandengan ilmu sosial dan seni kecuali berhubungan dengan geometri dan pola matematis. Untuk menghindari pemisahan atau spesialisasi bisa dilakukan hal: (1) korelasi; (2) aplikasi alat; dan (3) kesatuan tema.

Evaluasi bervariasi sesuai dengan tujuan yang ditetapkan. Dalam bidang humaniora, tes essay lebih banyak digunakan. Di bidang seni ekspresi dinilai berdasarkan kesetiaan terhadap subjektivitas personal dan terhadap standard citarasa dan keindahan. Matematka bisa dievaluasi dengan emahaman prinsip aksiomatik formal. Sains bisa dievaluasi dengan penetapan kriteria tertentu. Kurikulum akademik merasa bersalah atas dua macam kelemahan, yakni: (1) 
kelemahan isi, di mana sebagian orang menekankan pembelajaran pada segi apa yang diajarkan bukannya bagaimana proses pembelajaran terjadi; dan (2) kelemahan universalisme, yang menganggap bahwa beberapa bidang isi memiliki ciri universal tanpa melihat kondisi khusus setiap pembelajar. Untuk itu diperlukan adanya hubungan antar disiplin.

\section{Isu-isu Terbaru yang Menuntut Tanggapan}

Di dalam subbab ini akan dibahas mengenai enam macam isu terbaru mengenai kurikulum, yaitu (1) pengembangan pola pikir; (2) persaingan pendidikan antarbangsa; (3) pendidikan kejuruan; (4) kurikulum tersembunyi; (5) pendidikan moral; dan (6) pluralisme kultural. Keenam hal tersebut penting untuk dibicarakan karena masing masing menuntut bentuk dan isi kurikulum yang berbeda. Namun dalam hal ini, hanya akan dibahas mengenai hal-hal yang terkait dengan keenam isu tersebut tanpa memberikan satu pilihan yang pasti untuk diberlakukan. Meskipun setiap isu tersebut memiliki kelebihannya masingmasing, anda hanya dituntut untuk mengetahui bahwa hal tersebut merupakan salah satu contoh dari sekian banyak isu yang perlu mendapatkan tanggapan dalam bentuk kurikulum.

\section{a. Kurikulum Pengembangan Pola Pikir}

Selama ini, kurikulum kebanyakan dianggap berhubungan dengan pengembangan kekuatan mental. Satu pandangan bahwa pola pikir - kekuatan intektual untuk mengingat dan penalaran - bisa dikembangkan dengan baik melalui pengajaran sejenis subjek yang benar. Sementara pendapat lain menyatakan bahwa tidak ada satu subjek pun yang bisa dikatakan intelektual. Sementara itu Dewey menyatakan bahwa setiap subjek pasti bersifat intelektual jika intelektual itu tidak diartikan sebagai struktur melainkan fungsi sebagai suatu kekuatan untuk mengawali dan membimbing sebuah temuan dan refleksi yang signifikan. Pada tahun 1984, Commettee of Ten menyatakan bahwa tujuan utama pendidikan adalah untuk melatih pikiran, meskipun di antara anggotanya saling berbeda pendapat subjek apa yang bisa mewakili tujuan tersebut - bahasa dan pengetahuan kelasik atau matematika dan sains.

Akhirnya mereka berakhir pada suatu kesepakatan bahwa apapun subjeknya bisa tergolong dalam kajian ini jika mampu memberikan proses observasi, mengingat, ekspresi dan penalaran. Namun akhirnya kesepakatan tersebut mendapat serangan dari berbagai pihak. Teori baru untuk mengajarkan pola berpikir menekankan bahwa pengetahuan tidaklah penting sebagai sebuah disiplin mental, namun pengetahuan akan menjadi penting sebagai suatu cara konseptualisasi situasi, mengindentifikasi pola, dan mengorganisasikan informasi sehingga masalah baru dalam lingkup subjek tersebut bisa diselesaikan. Jenis pendidikan yang berbeda akan memberi hasil yang berbeda atas penalaran mengenai berbagai kejadian hidup.

Fokus dari kurikulum pengembangan pola pikir, ialah: (1) tujuan rekonstruksional sosial berpikir; (2) Tujuan humanistik berpikir; dan (3) Tujuan akademik berpikir. Tujuan rekonstruksional sosial berpikir, rekonstruksionis sosial menekankan pada berpikir kritis dan menunjukkan skeptisme sehat 
mengenai dunia, masyarakat dan sekolah mereka. Berpikir kritis lemah adalah menyusun argumen-argumen untuk mempertahankan pandangannya. Sedangkan berpikir kuat adalah kemampuan untuk mengkritisi pola pikirnya sendiri dan menyusun argumen yang terkuat bertentangan dengan pandangannya sendiri.

Tujuan humanistik berpikir, berpikir kreatif nilai humanis adalah kemampuan untuk menyusun beberapa ide guna memenuhi kebutuhan individual; yang bisa dilakukan dengan mengajarkan strategi dan syarat-syarat kondusif untuk berpikir kreatif. Beberapa kurikulum semacam ini memberikan pelatihan untuk mencari dan menciptakan sesuatu yang baru. Biasanya program berpikir kreatif memerlukan fluency, flexibility, exploring, elaborating, dan risk-taking. Tujuan akademik berpikir, akademisi akan menghargai modus paradigmatik atau logisilmiah. Modus ini mendasrkan pada kategorisasi, konseptualisasi, dan operasi untuk membentuk dan menghubungkan kategori. Ada tiga pengetahuan yang diajarkan untuk mengembangkan pemikiran akademik: (1) operasi dasar seperti klasifikasi, generalisasi, deduksi; (2) strategi penyelesaian masalah; dan (3) pengetahuan khusus ranah.

\section{b. Persaingan Kurikulum: Sebuah Perbandingan Internasional}

Apakah Pendidikan di Amerika tertinggaldibandingkan dengan negara lain? Jika iya, apa yang harus dilakukan? Pertanyaan tersebut mengundang banyak kontroversi. Ada anggapan bahwa pendidikan di Jepang dan China produktivitasnya selalu meningkat - terutama di bidang sains dan matematika - jika dibandingkan dengan produkticitas di Amerika. Banyak juga yang mengatakan bahwa data tentang hal itu masih harus dipertanyakan apalagi jika Amerika harus meniru negara-negara pesaing. Ada sebuah tes yang dilakukan oleh Stevenson dan Stigler pada siswa di sekolah-sekolah China, Jepang, Taiwan, dan Amerika yang hasilnya banyak memojokkan Amerika, bahwa dalam beberapa lingkup Amerika berada di bawah negara-negara yang lain.

Tabel 1 Persentase Hasil Skala Matematika Usia 13 Tahun

\begin{tabular}{|c|c|c|c|c|c|}
\hline Negara/Propinsi & + dan - & Sederhana & 2- langkah & $\begin{array}{l}\text { Memahami } \\
\text { konsep }\end{array}$ & Intr. Data \\
\hline Korea & 100 & 95 & 78 & 40 & 5 \\
\hline Quebec (Perancis) & 100 & 97 & 73 & 22 & 2 \\
\hline British Columbia & 100 & 95 & 69 & 24 & 2 \\
\hline Quebec (Inggris) & 100 & 97 & 67 & 20 & 1 \\
\hline New Brunswick (Ingg) & 100 & 95 & 65 & 18 & 1 \\
\hline Ontario (Inggris) & 99 & 92 & 58 & 16 & 1 \\
\hline New Brunswick (prcs) & 100 & 95 & 58 & 16 & 1 \\
\hline Spanyol & 99 & 91 & 57 & 12 & $<1$ \\
\hline Inggris Raya & 98 & 87 & 55 & 18 & 1 \\
\hline Irlandia & 98 & 86 & 55 & 18 & 2 \\
\hline Ontario (Prcs) & 99 & 85 & 40 & 7 & 0 \\
\hline Amerika & 97 & 78 & 40 & 9 & 1 \\
\hline
\end{tabular}

Sumber: McNeil (2006) 
Berdasarkan data Tabel 1 nampak bahwa dalam bidang matematika, Amerika menduduki tempat yang paling rendah di antara negara/provinsi pesaing. Namun angka tersebut tidak bisa mewakili kondisi sebenarnya, karena setiap negara memiliki kekhususan sendiri sehingga mampu meraih skor tinggi untuk bidang tertentu namun tidak untuk bidang yang lain. Berikut adalah ilustrasi untuk bidang ilmu pengetahuan.

Tabel 2 Persentase Hasil Skala Ilmu Pengetahuan Usia 13 Tahun

\begin{tabular}{lccccc}
\hline \multicolumn{1}{c}{ Legara/Propinsi } & $\begin{array}{c}\text { Tahu fakta } \\
\text { Sehari2 } \\
\text { Level 300 }\end{array}$ & Sederhana & $\begin{array}{c}\text { Analisis } \\
\text { Levsperm } \\
\text { level 500 }\end{array}$ & $\begin{array}{c}\text { Pengalaman } \\
\text { menengah } \\
\text { Level 600 }\end{array}$ & $\begin{array}{c}\text { Intr. Penga } \\
\text { laman } \\
\text { Level 700 }\end{array}$ \\
\hline British Columbia & 100 & 95 & 72 & 31 & 4 \\
Korea & 100 & 93 & 73 & 33 & 2 \\
Inggris Raya & 98 & 89 & 59 & 21 & 2 \\
Quebec (Inggris) & 99 & 92 & 57 & 15 & 1 \\
Ontario (Inggris) & 99 & 91 & 56 & 17 & 2 \\
Quebec (Perancis) & 100 & 91 & 56 & 15 & 1 \\
New Brunswick (Ingg) & 99 & 90 & 55 & 15 & 1 \\
Spanyol & 99 & 88 & 53 & 12 & 1 \\
Amerika & 96 & 78 & 42 & 12 & 1 \\
Irlandia & 96 & 76 & 37 & 9 & 1 \\
Ontario (Prcs) & 98 & 79 & 35 & 6 & $<1$ \\
New Brunswick (Ingg) & 98 & 78 & 55 & 7 & $<1$ \\
\hline
\end{tabular}

Sumber: McNeil (2006)

Banyak orang yang meragukan mengenai data yang menunjukkan bahwa Amerika berada di bawah negara-negara yang lain dalam hal matematika dan sain. Data mengenai kekalahan Amerika dari negara lain tersebut dianggap tidak valid, dengan alasan bahwa ada kesalahan dalam hal penetapan tujuan, nilai dan organisasi dari pemerolehan data tersebut. Tidaklah realistis mengukur kemampuan seseorang hanya sebagian dari seluruh kemampuan yang ada, misalnya, hanya dari kemampuan matematikanya saja, sain saja atau bahasa saja; sedangkan Amerika memiliki nilai egalitarianisme, utilitarianisme, dan individualisme. Jadi angka tersebut di atas tidak mewakili kondisi hasil belajar siswa Amerika.

\section{c. Pendidikan kejuruan}

Ada empat masalah yang dijumpai oleh perumus kurikulum kejuruan, yaitu: (1) tujuan: apakah pendidikan kejuruan dimaksudkan untuk mengembangkan intelektual, atau untuk membekali siswa dengan ketrampilan yang bisa dijual? (2) akses: apakah pendidikan kejuruan diperuntukkan bagi siswa yang lamban atau juga untuk yang cerdas? Apakah pendidikan dirancang sesuai dengan lembaga pendidikan atau sesuai dengan dunia kerja? Apakah pendidikan dikhususkan untuk laki-laki atau jua untuk perempuan? (3) kandungan: seberapa kemampuan pendidikan kejuruan menyesuaikan kebutuhan ekonomi di masa kini dan masa datang? Dan (4) organisasi: apakah pendidikan kejuruan disusun untuk memenuhi kesenjangan antara program kejuruan di sekolah dengan tuntutan kerja? Perbedaan tujuan untuk mendapatkan pendidikan kejuruan. Trend di 
Amerika banyak berkembang suatu pendapat bahwa masyarakat kelas mengah ke atas sebaiknya mendapatkan pendidikan klasik dengan grammar Latin, sedangkan masyarakat mengah ke bawah memilih pendidikan kejuruan untuk mampu mempertahankan hidup. Namun dalam kenyataan sekarang, banyak bidang kejuruan yang menuntut kemampuan intelektual yang tinggi untuk menghadapi majunya perkembangan teknologi berkaitan dengan bidang pekerjaan.

Rasionalnya, perkembangan ilmu pengetahuan mengubah pendapat klasik bahwa pendidikan kejuruan hanya untuk golongan bawah. Dalam perkembangannya, kurikulum meliputi pendidikan yang bersifat ketrampilan manual sebagai strategi pembelajaran belajar dengan perbuatan, yang merupakan salah satu proses pembelajaran. Pemikiran baru mengenai tujuan pendidikan kejuruan dirintis pemerintah yang sekarang menaruh perhatian pada ilmuwan dan insinyur yang sekaligus memiliki ketrampilan sebagai angkatan kerja yang mampu bersaing di pasar kerja internasional. Ketrampilan semacam itu kemudian disebut sebagai kemampuan, yakni: (1) mengorganisasikan sumber daya; (2) menjalankan kemampuan interpersonal; (3) mengkomunikasikan informasi dan proses komputer; (4) memilih teknologi yang sesuai; dan (5) memahami rancang bangun sebuah sistem baru. Di dalam pendidikan kejuruan, siswa bisa belajar untuk bertanya: (1) sebuah proses yang mencakup peranan serta bagaimana keuntungan didapatkan; (2) bagaimana pekerjaan berhubungan dengan lingkungan, diri sendiri, masyarakat; dan (3) apa artinya memiliki sebuah pekerjaan.

Selama ini pendidikan kejuruan dituduh telah menyababkan diskriminasi kelas sosial, yang memunculkan kelas-pekerja yang dimasukkan ke sekolah namun tidak mendapatkan pendidikan akademik. Namun sekarang pendapat tersebut telah bergeser dan banyak lembaga pendidikan menawarkan pendidikan kejuruan berteknologi tinggi yang diperlukan orang-orang yang memiliki ketrampilan tinggi. Terlebih lagi pendidikan kejuruan sekarang diangap netral dari diskriminasi gender, yang bisa diikuti oleh semua jenis kelamin. Untuk mendapatkan ketrampilan dasar, pendidikan kejuruan memberikan kemampuan membaca, menulis, matematika dan sains. Beberapa sekolah menambah dengan subjek pilihan seperti: otomotif, pertukangan, kerajinan metal yang didukung dengan keunggulan komunikasi, konstruksi, transparansi, dan manufakturing.

Reorganisasi pendidika kejuruan dimaksudkan untuk mengisi jarak antara program kejuruan di sekolah dengan permintaan pasar kerja. Jenis reorganisasi lain adalah penambahan program baru untuk melayani berkembangnya industri, yang disebut sebagai program 'quick strart'. Kamitraan antara lembaga pendidikan dan pengguna lulusan dikembangkan, sehingga kualitas lulusan akan menjadi tanggung jawab bersama antara lembaga pendidikan dan pengguna lulusan. Program-program pendidikan kejuruan terbaru menawarkan subjek yang jauh dari sederhana yang mencakup ketrampilan menyelesaikan masalah serta kerja tim.

\section{d. Kurikulum Tersembunyi}

Kurikulum tersembunyi diartikan sebagai pembejalaran yang tidak diorganisasikan oleh institusi tertentu. Adanya kurikulum tersembunyi 
menunjukkan bahwa hasil dari pembelajaran di sekolah tidak bisa diketahui secara formal. Gordon adalah orang pertama yang mencetuskan pernyataan bahwa sistem informal berpengaruh pada apa yang dipelajari - kurikulum tersembunyi. Gordon menyatakan bahwa siswa terikat pada tiga subsistem: (1) sistem formal kurikulum; (2) sistem semiformal, aktivitas dan kelompok; dan (3) sistem informal, persaingan, jarak, kelompok lain. Guru memegang peranan yang sangat penting dalam mengandalikan komunikasi di antara masyarakat sekolah. Tipe atau jenis komunikasi yang dilakukan di antara anggota masyarakat sekolah akan membentuk perilaku lulusan yang seringkali menjadi lebih dari apa yang diajarkan. Guru semestinya mengetahui unsur-unsur informal positif yang bisa dikembangkan untuk memperoleh lulusan yang tidak hanya cakap secara intelektual namun juga diterima di masyarakat luas. Bentuk komunikasi tersebut berada dalam lingkup kurikulum tersembunyi.

Ada sementara pendapat bahwa sekolah bukanlah merupakan tempat yang terbuka untuk segala jenis ide dan pemikiran, namun pemikiran yang harus diserap siswa diberikan melalu seleksi dan panekanan tertentu. Dengan demikian siswa akan mempercayai: (1) konfrontasi merupakan kegagalan; (2) kemiskinan merupakan kesalahan individu bukan kesalahan kelompok; dan (3) tidak ada kelas pekerja di Amerika. Kurikulum tersembunyi memiliki pesan tersembunyi yang menunutut siswa melihat dunia sebagai kelompok masyarakat. Kurikulum tersembunyi bisa digunakan sebagai sarana bagi perkembangan moral. Melalui interaksi siswa bisa mempelajari suasana keadilan, kerjasama dalam melaksanakan aktivitas bersama untuk memperoleh prestasi secara adil. Kurikulum tersembunyi merupakan factor penentu untuk menumbuhkan integrasi. Strategi interaksi menjadi sangat penting dalam menghadapi: ras yang berbeda, membangun persahabatan, pemahaman antar cultur. Kurikulum tersembunyi bisa dibuat konsisten dengan memperhatikan hal-hal: (1) organisasional (waktu, fasilitas, dan materi); (2) interpersonal (guru-siswa, guru-administratur, guruorangtua siswa, siswa-siswa); dan (3) institusional (kebijakan, prosedur rutin, ritual, strultur social, ekstrakurikuler).

\section{e. Pendidikan Moral dan Karakter}

Orang saat ini mulai mempertanyakan tentang benar atau salah dan melakukan penilaian mengenai benar dan salah tersebut. Banyak sekali konflik yang ditimbulkan karena pelecehan seksual, rasial, narkoba, dan politik. Hal itu menyadarkan mereka bahwa dasar moral yang kuat akan sangat diperlukan dalam kondisi semacam ini. Isu tentang moral tersebut diupayakan untuk dimasukkan ke dalam kurikulum, meskipun bukan barang gampang. Ada empat macam pendekatan yang bisa digunakan untuk mertancang kurikulum dengan muatan moral: (1) nihilistic - yang menolak adanya nilai benar dan salah; (2) autonomic nilai benar dan salah ditentukan oleh dirinya sendiri; (3) heteronomik - manusia tidak membuat nilai benar dan salah, namun menemukannya. Nilai itu bisa diajarkan; dan (4) telenomik - nilai benar dan salah dilihat secara menyeluruh, sebagai perwujudan abadi dari ideology yang bersifat objektif dan normatif. Dalam kaitannya dengan kuikulum, sekolah diharapkan mampu mengembangkan 
deliberasi moral yang berfokus pada masalah social dan individual, dengan menawarkan perspektif yang relevan dari sebuah dimensi khusus.

Kohlberg menyatakan adanya tahapan-tahapan perkembangan moral mulai dari tanggapan pembelajar terhadap nilai baik dan buruk sampai pada pembuatan keputusan yang didasarkan pada prinsip keadilan. Fokus yang sempit pada keputusan moral merupakan faktor terpenting dalam perilaku moral. Pertumbhan moral pada pembelajar bisa dipacu melalui proses pembelajaran yang terintegrasi dalam kurikulum. Namun ada kelemahan dari teori ibi yaitu bahwa faktor subjektif diabaikan, padahal bisa menjadi sangat menonjol dalam kerangka membuat sebuah keputusan moral. Klarifikasi nilai merupakan salah satu pendekatan di dalam pendidikan moral. Pendekatan ini akan lebih menunjukkan konflik moral terhadap pembelajar daripada meminta pendapatnya mengenai baik buruk. Pendekatan ini diangap membantu siswa untuk: (1) lebih bertujuan, karena ada skala prioritas, (2) lebih produktif, karena mereka menganalisis di mana aksi membawa mereka, (3) lebih kritis, karena mereka belajar dari kesalahan orang lain, dan (4) lebih bisa memperbaiki hubungan dengan orang lain. Dasar dari pendidikan tingkah laku adalah bahwa orang dewasa membuat aturan serta menjelaskannya dan yang muda mengikutinya; dengan standar etika ideal, keadilan, menghargai, kesetiaan, dan tugas.

\section{f. Pluralisme Kultural}

Kurikulum pluralisme kultural memberikan perhatian yang spesifik terhadap keragaman kultur yang dimiliki suatu bangsa. Pendidikan dengan kurikulum pluralisme kultural akan menjadikan siswa sadar mengenai keragaman kultur yang mengakibatkan perbedaan pola pikir serta nilai-nilai yang dimiliki oleh masyarakat. Dengan menyadari adanya perbedaan tersebut, siswa akhirnya akan bisa menghargai orang lain dalam kondisi ini. Sleeter dan Grant mengembangkan taksonomi terhadap lima pendekatan multikultural, yani: (1) mengajarkan perbedaan kultural, pendekatan ini akan penyesuaian perbedaan kultural siswa dalam suatu kurikulum. Srategi pembelajaran bisa dilakukandengan mengadaptasikan metode pembelajaran bagi golongan kultur minoritas. Pendekatan ini memberikan kesempatan yang sama bagi kelompok sosial yang berbeda untuk bersaing secara sehat dan mengembangkan diri, misalnya dengan cara: tidak mengajarkan rasisme, kelas sosial pada orang kulit putih; (2) hubungan masyarakat, pendekatan ini dilakukan dengan perlakuan yang sama terhadap kelompok siswa yang berbeda untuk meminimalkan kecemburuan dan konflik sosial; (3) kajian etnik, tujuan utama pendekatan ini adalah untuk menumbuhkan rasa penerimaan dan penghargaan kepada setiap kelompok yang berbeda ke dalam kelompoknya; (4) kebhinekaan kultural, pendekatan ini menekankan pada pendidikan multikultural yang mengedepankan persamaan hak atas keadilan, pendidikan, dan distribusi kekuasaan; dan (5) rekonstruksi sosial, tujuan dari pendekatan ini adalah untuk menyiapkan pemuda dalam melakukan aksi perlawanan terhadap pembedaan struktural, seperti gender, kelas sosial.

Salah satu pendidikan dalam plralisme kultural adalah pendidikan bilingual, di mana perbedaan kultural diakui dan dilayani dengan penggunaan dua bahasa atau lebih, dengan kelebihan: (1) mengurangi ketegangan bagi siswa non- 
Inggris; (2) memperbaiki hubungan sekolah-rumah; dan (3) memberi suasana kondusif bagi siswa non-Inggris. Program yang bisa ditawarkan meliputi: (1) submersion - memasukkan siswa non-Inggris ke dalam masyarakat berbahasa Inggris; (2) program pull-out - mengajarkan bahasa Inggris sebagai bahasa kedua kepada siswa non-Inggris; dan (3) program transisi - siswa non-Inggris menerima pelajaran dalam bahasa mereka dengan sekali waktu mempelajari bahasa Inggris sebagai bahasa kedua.

\section{Penutup}

Para penganut kurikulum humanis menyarankan bahwa sebuah kurikulum seharusnya memberikan wadah bagi pengalaman pribadi yang memuaskan bagi setiap siswa. Para humanis baru merupakan pelaku aktualisasi diri yang melihat kurikulum sebagai sebuah proses liberasi yang memenuhi kebutuhan akan pertumbuhan dan integritas pribadi. Namun demikian para humanis tersebut jangan diartikan sebagai pendidik dalam tradisi seni liberal yang menganggap humaniora sebagai disiplin ilmu yang terpisah, seperti: seni, musik, dan sastra, dan mereka yang berusaha untuk berhubungan dengan manusia hanya melalui karya kultural. Para rekonstruksionis sosial menekankan kebutuhan sosial yang terdapat pada kepentingan individual. Mereka menyatakan bahwa tanggung jawab sebuah kurikulum adalah untuk melakukan reformasi sosial dan menurunkan masa depan yang lebih baik bagi masyarakat. Mereka menekankan perkembangan nilainilai sosial dan penerapannya di dalam proses berpikir kritis.

Teknologis melihat penyusunan kurikulum merupakan sebuah proses teknologis untuk meraih apa yang dikehendaki oleh pembuat kebijakan. Mereka menganggap dirinya bertanggung jawab untuk menciptakan realita yang menunjukkan bahwa kurikulum yang mereka susun sesuai dengan tujuan yang dikehendaki. Efisiensi dan akuntabilitas merupakan nilai akhir bagi seorang teknolog. Orientasi mereka tidaklah netral karena teknolog memiliki komitmen terhadap suatu metode yang akhirnya akan berpengaruh terhadap tujuan dan isi kurikulum. Orang yang memiliki orientasi akademik memandang kurikulum sebagai kendaraan yang bisa digunakan oleh pembelajar untuk mengenali disiplin ilmu dan mengenali bidang-bidang ilmu yang terorganisir. Mereka melihat isi yang terorganisir dari disiplin ilmu tersebut lebih sebagai sebuah kurikulum yang harus dicapai daripada sebuah sumber informasi untuk mendalami masalah personal dan lokal. Orang yang termasuk dalam kategori ini menganggap bahwa kurikulum akademik merupakan cara terbaik untuk mengembangkan pemikiran bahwa penguasaan sejenis pengetahuan yang biasa ditemukan pada kurikulum semacam itu akan membentuk cara berpikir rasional. 


\section{DAFTAR RUJUKAN}

Fosnot, C. T. 1996. Constructivism: theory, perspectives, and Practice. London: Teachers College Press, Columbia University.

Gagnon Jr, G.W., and Collay, M. 2001. Designing for Learning: Six Elements in Constructivist Classrooms. Thousand Oaks, California: Corwin Press, Inc.

Hergenhahn, B.R., and Olson, M.H. 2008. Theories of Learning. England: Pearson Education.

Joyce, B., Weil, M., and Calhom, E. 2000. Models of Teaching, London: Allyn and Bacon.

Kembler, D. 2000. Action Learning and Research. London: British Libraray Cataloguing in Publication Data.

McNeil, J. D. 1996. Curriculum: A Comprehensive Introduction. University of California, Los Angeles: Harper Collins College Publisher.

Munby, J. 1998. Communicative Syllabus Design: A Sociolinguistic Model for Defining the Content of Purpose Specific language Programes. The Eidenburgh Building, Cambridge, United Kingdom: Cambridge University Press.

Oliva, P. F. 1982. Developing the Curriculum. Georgia Southern College, Boston: Little, Brown and Company.

Yalden, J. 1985. The Communicative Syllabus: Evolution, Design and Implementation. Headington Hill Hall, England: Pergamon Press Ltd. 